\title{
Caesarean scar pregnancy
}

\author{
Yves Jacquemyn, ${ }^{1}$ Mieke Kerremans, ${ }^{2}$ Bart Op de Beeck, ${ }^{2}$ Cecile Colpaert ${ }^{2}$
}

1 Obstetrics Department, UZA, Edegem, Belgium;

2UZA, Edegem, Belgium

Correspondence to Professor Yves Jacquemyn, yves.jacquemyn@uza.be

\section{Summary}

Faced with difficulty discriminating between placenta and myometrium in a patient with three previous caesarean sections, MRI provided definitive diagnosis of caesarean scar pregnancy, allowing for a save and uneventful planned surgical procedure.

\section{BACKGROUND}

When in doubt of the exact gestational location on first trimester ultrasound, in patients with a previous caesarean section, MRI can help define the exact location.

\section{CASE PRESENTATION}

A G4P3, aged 31 years, with three previous caesarean sections for fetopelvic disproportion presented at 9 weeks amenorrhoea with an unplanned pregnancy. Transvaginal ultrasound demonstrated a viable 9 week embryo, there was doubt about the atypical aspect of the placenta: no clear distinction between placenta and myometrium was possible, neither in gray scale nor with colour Doppler imaging (figures 1 and 2). Differential diagnosis included placenta percreta and caesarean scar pregnancy. Abdominal obesity made further transabdominal ultrasound unfeasible. MRI was performed which showed an embryo with the gestational sac at the site of the caesarean scar (ventral side of the uterine corpus close to the endocervix) and extra-uterine extension of placental tissue (figure 3).

After extensive counselling of the patient concerning all possible options including systemic and local methotrexate,

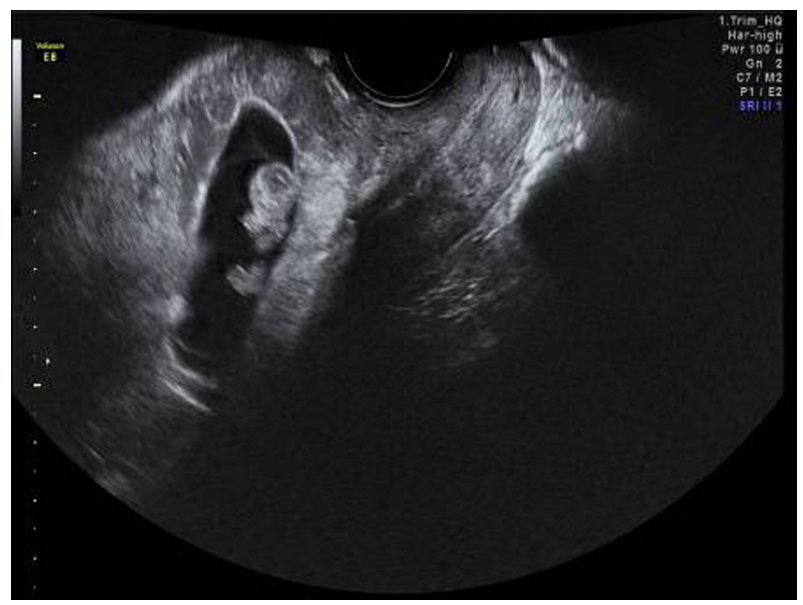

Figure 1 Ultrasonography at 9 weeks amenorrhoea, no distinction between placenta and myometrium. vascular embolisation and hysterectomy, together with the patient it was decided to perform abdominal hysterectomy. We visualised the fetal sac through the previous caesarean scar (figures 4 and 5). The postoperative period was without complications.

Histopathology confirmed the myometrium on the side of the scar was almost completely replaced by trophoblastic tissue (figure 6).

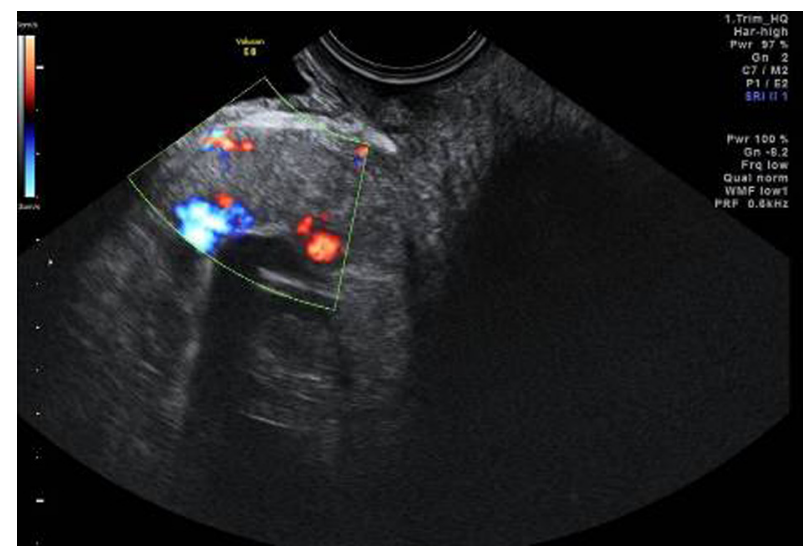

Figure 2 Colour Doppler Ultrasound, no clear delineation between placenta and myometrium, placenta percreta or caesarean scar pregnancy.

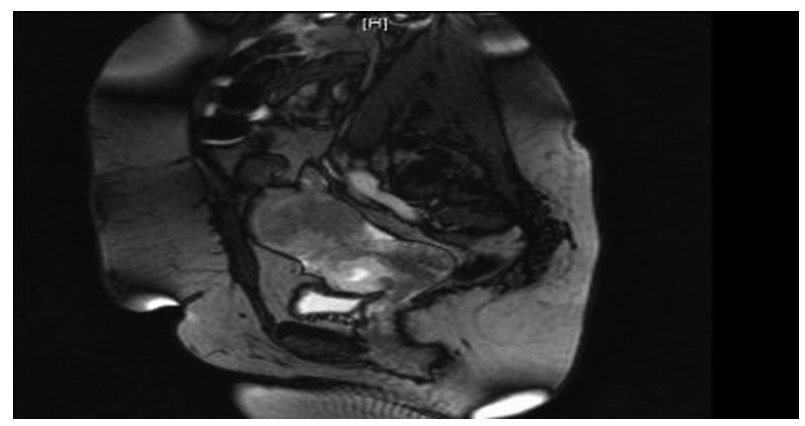

Figure 3 MRI: gestational sac in caesarean scar not communicating with the uterine cavity. 


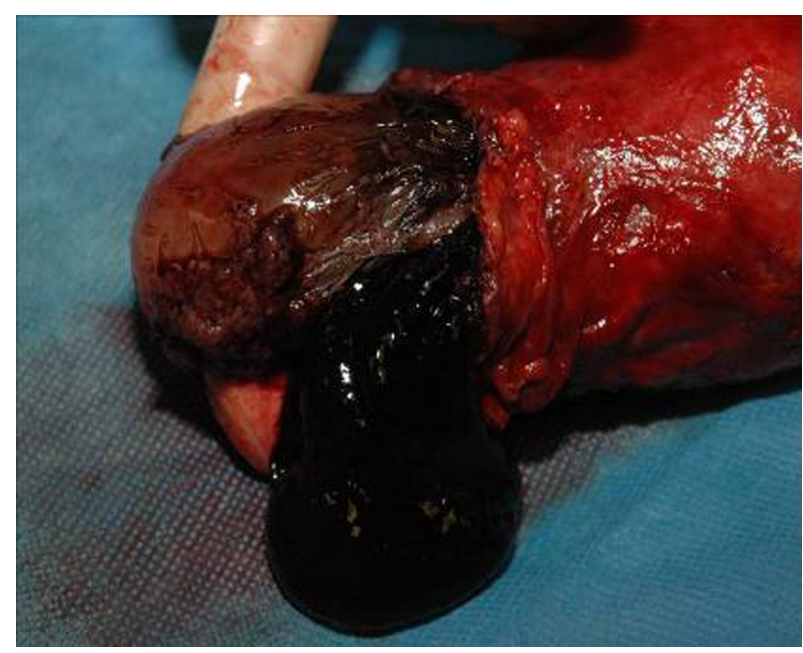

Figure 4 Hysterectomy specimen showing the bulging gestational sac.

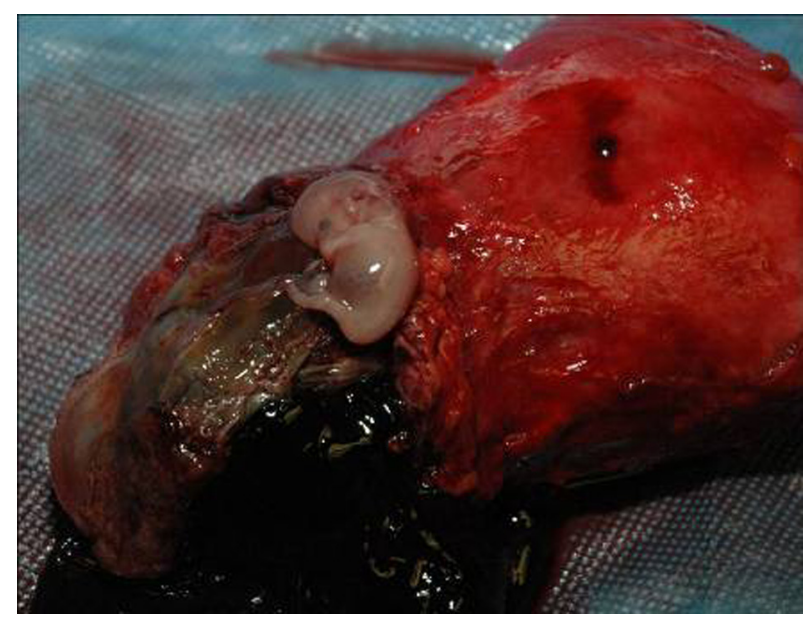

Figure 5 Hysterecomy specimen, gestational sac opened, demonstrating embryo at 11 gestational weeks on the moment of surgery.

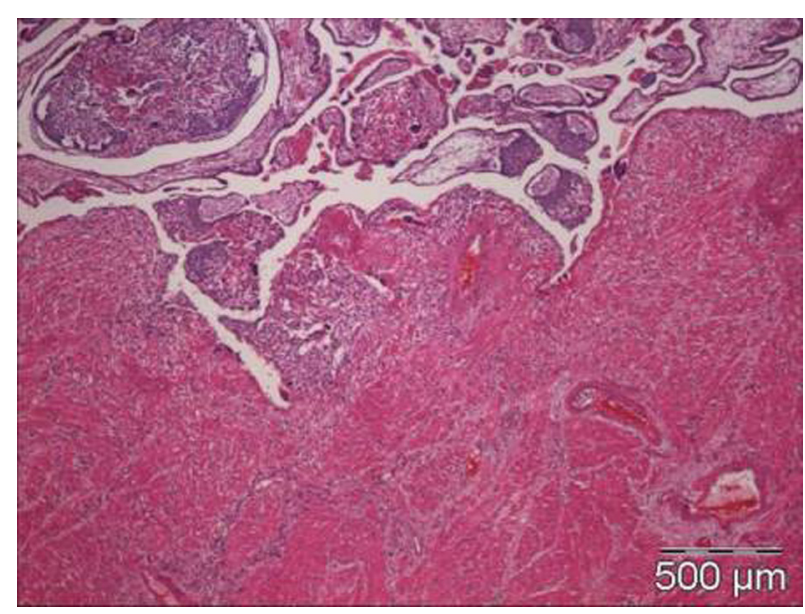

Figure 6 Histopathology: the myometrium on the side of the scar was grown with trophoblastic tissue and placental tissue.

\section{DIFFERENTIAL DIAGNOSIS}

- Placenta percreta

- Caesarean scar pregnancy.

\section{TREATMENT}

Laparotomy with hysterectomy.

\section{OUTCOME AND FOLLOW-UP}

Laparotomy: procedure without any complication.

\section{DISCUSSION}

Caesarean scar pregnancy, defined as a gestation completely surrounded by myometrium and fibrous tissue of the previous caesarean section scar, separated from the endometrial cavity and endocervical canal, ${ }^{1}$ is rare with a reported incidence between $1 / 1800$ and $1 / 2200$ of all pregnancies but the true incidence is unknown. ${ }^{2}$

Expectant management is possible in caesarean scar pregnancies with the risk of life-threatening bleeding and urgent hysterectomy. ${ }^{3}$ Both because of the risk of massive bleeding and because the patient expressed the wish never to conceive again we choose to perform hysterectomy. It is important to have a high index of suspicion for caesarean scar pregnancy to diagnose it early and to apply adequate treatment. ${ }^{4}$ Caesarean scar pregnancy has significant morbidity and mortality.

The aetiology is unclear. Risk factors are previous caesarean section, myomectomy, invitro fertilisation, curettage and manual removal of the placenta. ${ }^{5}$

The diagnostic criteria ${ }^{6}$ are (a) empty uterine cavity and cervical canal (as opposed to placenta percreta); (b) development of gestational sac in the anterior uterine wall at the site of the previous caesarean section scar; (c) evidence of functional trophoblastic circulation at Doppler examination, defined by the presence of an area of increased peritrophoblastic vascularity; (d) absence of healthy myometrium between the bladder and the sac; (e) demonstration of a discontinuity at the level of the anterior wall of the uterus.

In this case it was impossible to reach a definitive diagnosis with ultrasound alone and MRI proved to aid in reaching the diagnosis, in this case showing the myometrium completely surrounding the gestation with no communication to the endometrial cavity.

To date there is not a standard treatment, different therapeutic options have been published including local and/or systemic methotrexate, eventually combined with local injection of $\mathrm{KCl},{ }^{7}$ dilatation and curettage (as this is associated with a very high risk for life-threatening haemorrhage, this should not be performed), laparoscopy with removal of the fetal sac and large intracorporal sutures, laparotomy with removal of the caesarean scar pregnancy or with hysterectomy. ${ }^{8}$

Conservative methotrexate therapy can results in massive haemorrhage necessitating urgent laparotomy. Prophylactic embolisation ${ }^{9}$ of the uterine arteries has been proposed.

To conclude, early diagnosis and immediate treatment of caesarean scar pregnancy is of utmost importance, as it 


\section{BMJ Case Reports}

makes termination an option in the first trimester. Because the caesarean section rate is still increasing, the incidence of caesarean scar pregnancies will be rising in the future. In case of doubt MRI can help make the diagnosis.

\section{Learning points}

- In every patient with a previous caesarean scar, the exact location of the pregnancy should be noted at the first ultrasound.

- Atypical aspect of the placenta without clear distinction from the myometrium raises the possibility of a caesarean scar pregnancy.

- MRI can aid in the diagnosis, especially in obese women.

Competing interests None.

Patient consent Obtained.

\section{REFERENCES}

1. Tan G, Chong YS, Biswas A. Caesarean scar pregnancy: a diagnosis to consider carefully in patients with risk factors. Ann Acad Med Singap 2005;34:216-9.

2. Tolino A, Battista L, Chiacchio G, et al. Cervico-isthmic pregnancy developing within the scar of a previous cesarean section: a case report. Gynecol Surg 2010; 7:43-7.

3. Yan CM. A report of four cases of caesarean scar pregnancy in a period of 12 months. Hong Kong Med J 2007;13:141-3.

4. Graesslin 0, Dedecker F Jr, Quereux C, et al. Conservative treatment of ectopic pregnancy in a cesarean scar. Obstet Gynecol 2005;105:869-71.

5. Chetty M, Elson J. Treating non-tubal ectopic pregnancy. Best Pract Res Clin Obstet Gynaecol 2009;23:529-38.

6. Jurkovic D, Hillaby K, Woelfer B, et al. First-trimester diagnosis and management of pregnancies implanted into the lower uterine segment cesarean section scar. Ultrasound Obstet Gynecol 2003;21:220-7.

7. Salomon LJ, Fernandez H, Chauveaud A, et al. Successful management of a heterotopic Caesarean scar pregnancy: potassium chloride injection with preservation of the intrauterine gestation: case report. Hum Reprod 2003; 18:189-91.

8. Rotas MA, Haberman S, Levgur M. Cesarean scar ectopic pregnancies: etiology, diagnosis, and management. Obstet Gynecol 2006;107:1373-81.

9. Sugawara J, Senoo M, Chisaka H, et al. Successful conservative treatment of a cesarean scar pregnancy with uterine artery embolization. Tohoku J Exp Med 2005;206:261-5.

This pdf has been created automatically from the final edited text and images.

Copyright 2012 BMJ Publishing Group. All rights reserved. For permission to reuse any of this content visit

http://group.bmj.com/group/rights-licensing/permissions.

BMJ Case Report Fellows may re-use this article for personal use and teaching without any further permission.

Please cite this article as follows (you will need to access the article online to obtain the date of publication).

Jacquemyn Y, Kerremans M, de Beeck BO, Colpaert C. Caesarean scar pregnancy. BMJ Case Reports 2012;10.1136/bcr.11.2011.5163, Published XXX

Become a Fellow of BMJ Case Reports today and you can:

- Submit as many cases as you like

- Enjoy fast sympathetic peer review and rapid publication of accepted articles

- Access all the published articles

- Re-use any of the published material for personal use and teaching without further permission

For information on Institutional Fellowships contact consortiasales@bmjgroup.com

Visit casereports.bmj.com for more articles like this and to become a Fellow

Keep up to date with all published cases by signing up for an alert (all we need is your email address) http://casereports.bmj.com/cgi/alerts/etoc 